\title{
The International Journal
}

ENTREPRENEURSHIP AND SUSTAINABILITY ISSUES

ISSN 2345-0282 (online) http://jssidoi.org/jesi/

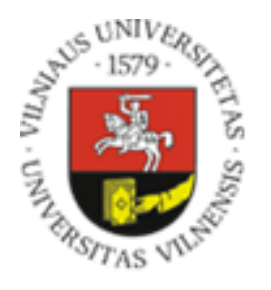

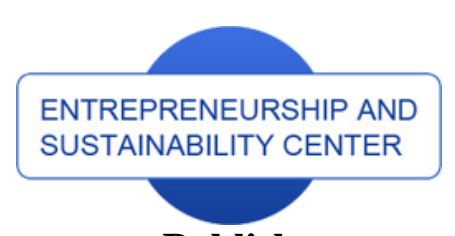

Publisher

http://jssidoi.org/esc/home

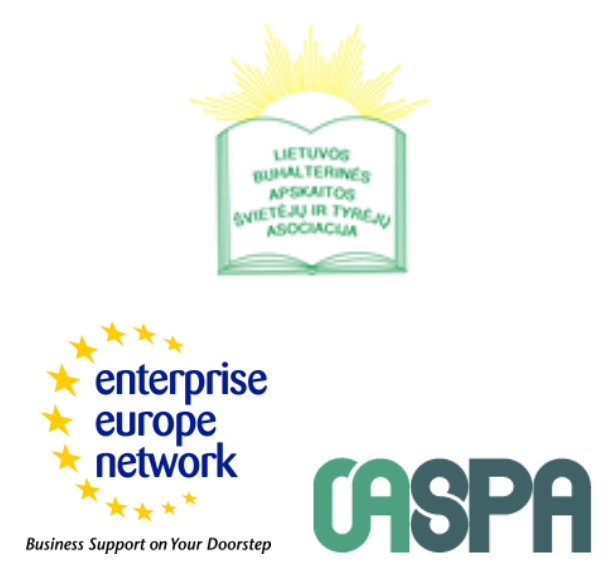

Scopus' Web of Science

\section{PROBLEMS AND SOLUTIONS OF ACCOUNTING AND EVALUATION OF BIOLOGICAL ASSETS IN LATVIA}

\author{
Iluta Arbidane', Iveta Mietule ${ }^{2}$ \\ ${ }^{1,2}$ Rezekne Academy of Technologies, Atbrivosanas aleja 115, Rezekne, Latvia, LV-4601 \\ E-mails: ${ }^{1}$ Iluta.Arbidane@rta.lv; ${ }^{2}$ Iveta.Mietule@rta.lv
}

Received 28 March 2018; accepted 10 May 2018; published 30 September 2018

\begin{abstract}
Activities in the field of agriculture deal with plants and animals constituting biological assets of the sector. From the point of view of accounting and valuation, biological assets is a scarcely investigated topic in Latvia, as well the object of the research only in general terms is reflected in Latvian legislation. That leads to confusion and uncertainty in evaluation and accounting of biological assets in the practical accounting. The subject of the study: evaluation and accounting of biological assets. The aim of the study is to explore and analyse problems of accounting and evaluation of biological assets in Latvia and to propose solutions. One of the research tasks is to explore the current legal base for evaluation and accounting of biological assets provided in the national legislation, to evaluate how it complies with the international accounting standards and to analyse the experience of other countries. The challenging issues of evaluation and accounting of biological assets in Latvia are defined in the research, possible solutions for improving the quality of accounting of biological assets are developed proposing the necessary amendments to the legislation and revisions to the methodological documents. Methods of the research: monographic/descriptive method, document analysis, and graphical analysis.
\end{abstract}

Keywords: biological assets, evaluation, accounting, agricultural

Reference to this paper should be made as follows: Arbidane, I.; Mietule, I. 2018. Problems and solutions of accounting and evaluation of biological assets in Latvia, Entrepreneurship and Sustainability Issues 6(1): 10-22. http://doi.org/10.9770/jesi.2018.6.1(1)

JEL Classifications: M410

\section{Introduction}

Agriculture is the sector, where accurate and correct counting and valuation of biological assets play a key role in the accounting and annual reporting process. "Biological assets" is a relatively new concept in the Latvian accounting system, so there are potential uncertainties about their evaluation and recording in the company's accounting system. The research problem: the legal acts of the Republic of Latvia do not sufficiently and 
ENTREPRENEURSHIP AND SUSTAINABILITY ISSUES

ISSN 2345-0282 (online) http://jssidoi.org/jesi/

2018 Volume 6 Number 1 (September)

http://doi.org/10.9770/jesi.2018.6.1(1)

unambiguously explain the principles of evaluation and accounting of biological assets. The study's aim: to explore and analyse problems of accounting and evaluation of biological assets in Latvia and to propose solutions. The subject: evaluation and accounting of biological assets. Methods of the research: monographic/descriptive method, document analysis, and graphical analysis. Novelty of the research: the normative acts on the basic principles of evaluation and accounting of biological assets in the Republic of Latvia have been investigated. In the process of the paper development, research and analysis of the available information was carried out, concluding what are the issues of the evaluation and accounting of biological assets and their possible solutions. The authors of the paper have examined the differences in evaluation and accounting of biological assets in Latvia, Estonia, and Lithuania.

Agriculture is one of the eldest human activities and has an important role in global economy by its generated economic resources (Mates, Grosu, 2009). The agriculture sector is an important element of the global economy, nevertheless accounting of its activities has had little attention from the accounting standard developers as most business applications focus on production, marketing, or tax reporting (Fischer, Marsh, 2013). As well agriculture accounting has attracted not as much of attention from the researchers and accounting standard regulators until the International Accounting Standard (IAS) 41-Agriculture was adopted (Herbohn and Herbohn, 2006).

The key production elements of an agricultural company are its biological assets, and the company profit depends on the efficiency of the management of these assets (Ore, 2011). Ore in her research has explored theoretical concepts in accordance with the International Accounting Standard (IAS) 41-Agriculture that could be important and may serve as a basis for elaboration of Latvian Accounting Standards (LAS) for "Biological Assets" or "Agriculture".

In Latvia, issues of accounting and evaluation of biological assets have been studied only by Ore (2011) and Jesemchika (2010). Despite the suggestions proposed by the authors, the legislator haven't paid appropriate attention to the legal regulations of accounting of biological assets. At the beginning of the century, in Latvia, eleven Latvian Accounting Standards (LAS) were developed, which along general lines are in accordance with accounting regulatory enactments, the European Community Law and the International Accounting Standards. LAS were not approved, consequently, they are not applicable at the moment. It should be noted that agriculture issues are not explained in any of the standards, contrary to the standards existing in Estonia and Lithuania. As there are no national accounting standards for the accounting of biological assets, the national legislation and laws as well as IAS 41-Agriculture are used in accounting.

When evaluating the number of agricultural enterprises in Latvia, it can be concluded that their number is noteworthy (Table 1).

Table 1. Changes in the number of agricultural enterprises from 2013 to 2017

\begin{tabular}{|c|c|c|}
\hline Year & Number of agricultural enterprises & $\begin{array}{c}\text { Share of agricultural enterprises in } \\
\text { the overall structure of enterprises } \\
(\%)\end{array}$ \\
\hline 2013 & 27517 & 16,6 \\
\hline 2014 & 26619 & 15,4 \\
\hline 2015 & 27299 & 15,0 \\
\hline 2016 & 28201 & 15,0 \\
\hline
\end{tabular}


ENTREPRENEURSHIP AND SUSTAINABILITY ISSUES

ISSN 2345-0282 (online) http://jssidoi.org/jesi/

2018 Volume 6 Number 1 (September)

http://doi.org/10.9770/jesi.2018.6.1(1)

Source: Compiled by the authors according to data of the Latvian Central Statistical Bureau

Table 1 shows the number of economically active enterprises, whose activity is forestry and agriculture by the NACE classifier. By legal form, they are self-employed persons, farms and fisheries, individual commercial entities, and commercial entities with the main type of activity - agriculture. In 2014, share of agriculture, forestry and fishery in the gross value added was 3,5\%; in $2015-3,4 \%$; in $2016-3,2 \%$. These indicators are similar in Lithuania and Estonia as well. In 2016, share of agriculture, forestry, and fishing was 3,3\% of the gross value added in Lithuania and 2,9\% in Estonia.

\section{Definition and classification of biological assets}

In Latvia, the principles for preparation of annual accounts, including classification and accounting of balance sheet items, are governed by the Law On the Annual Financial Statements and Consolidated Financial Statements (22.10.2015). The law states that the biological assets are labour or productive animals or plants that the company holds in order to obtain agricultural products for sale or to use them as additional biological assets. In Annex 1 to the regulatory enactment, a scheme balance sheet is established. According the law, biological assets are included under the following positions:

- Long-term investments;

- Current assets.

It must be concluded that the law and its binding regulations do not further clarify the concept of biological assets and do not specify the classification principles for animals and plants to be indicated as "Biological assets" under the item of long-term investments or current assets. The provisions for the use of certain items in the balance sheet stipulate that the item "Biological assets" is used only by a company, which in accordance with the international accounting standards, recognizes, assesses and reflects biological assets in the financial statements.

In accordance with IAS 41-Agriculture, the standards are applied to an agricultural product that is harvested from the biological assets of enterprise at the time of harvesting. Consequently, biological assets can be living animals or plants. The entity recognises a biological asset or agriculture produce only when the entity controls the asset as a result of past events, it is probable that future economic benefits will flow to the entity, and the fair value or cost of the asset can be measured reliably. Agricultural activity is the biological transformation of biological assets or the management of biological assets carried out by the enterprise in order to transform biological assets into agricultural products for sale or for use as the additional biological assets (IAS 41-Agriculture).

Biological assets are divided into groups that have some common characteristics. However, in order to divide biological assets in groups and their components, there must be a homogeneous nature of the assets and the purpose of their use. Agricultural products are products obtained from the company's biological assets. In turn, the finished products for sale are produced by processing agricultural products.

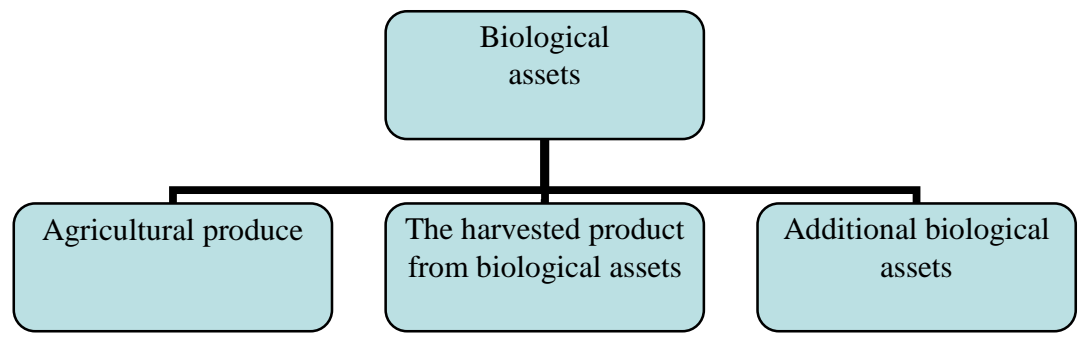

Fig.1. Transformation process of biological assets. 
ENTREPRENEURSHIP AND SUSTAINABILITY ISSUES

ISSN 2345-0282 (online) http://jssidoi.org/jesi/

2018 Volume 6 Number 1 (September)

http://doi.org/10.9770/jesi.2018.6.1(1)

Source: Compiled by the authors according to IAS 41-Agriculture

As shown in Figure 1, in the process of transformation of biological assets, products from biological assets are produced/ harvested, as well some biological assets are obtained from the assets themselves

Table 2. The most common biological assets, agricultural products and additionally obtained biological assets in Latvia

\begin{tabular}{|c|c|c|c|}
\hline $\begin{array}{l}\text { Biological } \\
\text { assets }\end{array}$ & Agricultural produce & $\begin{array}{c}\text { The harvested product from } \\
\text { biological assets }\end{array}$ & Additional biological assets \\
\hline Pigs & Pork, leather & $\begin{array}{l}\text { Pork products, leather } \\
\text { products }\end{array}$ & Piglets \\
\hline Rabbits & Meat, furskin & Meat products, fur & Rabbits \\
\hline Dairy cattle & Milk & Milk products & Calves \\
\hline Meat cattle & Beaf & Beaf proucts, leather & Calves \\
\hline Poultry & Eggs, poultry meat, feathers & $\begin{array}{l}\text { Poultry and egg products, } \\
\text { down }\end{array}$ & Chikens, ducklings, gooslings \\
\hline Bees & Honey, pollen, wax & $\begin{array}{l}\text { Wax products, bee bread, } \\
\text { homeopathic and cosmetic } \\
\text { products }\end{array}$ & Queen bees \\
\hline Potato plantings & Potatos & Potato starch, potato products & Potato seedlings \\
\hline Fruit and berry trees & Pickled fruits, berries, seeds & $\begin{array}{l}\text { Jam, juice, frozen products, } \\
\text { etc. }\end{array}$ & Saplings, sprouts and shoots \\
\hline $\begin{array}{l}\text { Ornamental plants, annuals and } \\
\text { perennials }\end{array}$ & $\begin{array}{l}\text { Cut flowers, ornamental bush } \\
\text { branchesm seeds }\end{array}$ & Floristry products & $\begin{array}{l}\text { Saplings, sprouts and shoots of } \\
\text { ornamental plants }\end{array}$ \\
\hline Trees planted in forest & Logs, seeds & Timber products & Saplings of trees \\
\hline Freshwater fish & Caught fish & Fish products & Fry \\
\hline
\end{tabular}

Source: Compiled by the authors according to IAS 41-Agriculture

The biological assets can be classified either as mature or immature assets. The mature biological assets are the ones that achieved harvest characteristics and therefore are consumable biological assets. This category also comprises the biological assets that can be periodically harvested (in case of the bearer biological assets) (Lefter, Roman, 2007).

Biological assets can be classified according to several qualities:

- time of use or time of preparation for use;

- signs of maturation or ripeness;

- possibility of gaining economic benefits several times, i.e., additional biological assets and agricultural produce.

According to the classification by duration of use or preparation for use, long-term biological assets are capable of producing agricultural products and/or additional biological assets, providing additional economic benefits to the enterprise over a period of more than 12 months. In turn, short-term biological assets include plants and animals 
ENTREPRENEURSHIP AND SUSTAINABILITY ISSUES

ISSN 2345-0282 (online) http://jssidoi.org/jesi/

2018 Volume 6 Number 1 (September)

http://doi.org/10.9770/jesi.2018.6.1(1)

that provide economic benefits for up to 12 months. Such classification of biological assets is economically justified because, indeed, each company invests funds with the idea of obtaining future economic benefits.

Classification of biological assets by signs of maturation or ripeness indicates to the biological assets whose production cycle exceeds 12 months (except for fattening cattle) and those that during the reporting period are unable to provide agricultural produce and/or additional biological assets in a certain quality. Using this classification, it is possible to obtain information about the potential cash flow expected in the next reporting period.

These two types of classifications allow biological assets to be divided into homogeneous groups. These classifications, depending on the needs of enterprises, can be modified and further categorized according the physical properties of biological assets. Creating a classification containing smaller groups makes accounting easier.

The classification of biological assets by capability providing economic benefits several times, i.e., additional biological assets and agricultural production. This type of classification of biological assets provides assistance in obtaining information about the possible cash flow not only in the following reporting year, but also over a longer period of time.

The authors believe that the first two types of classification of biological assets are the most advantageous from the accounting point of view, while agricultural companies that want to maximize profits should use the third type of biological asset classification.

\section{Recognition and evaluation of biological assets}

IAS 41 "Agriculture" can serve as a guideline. The application of this standard provides the possibility to evaluate biological assets, using equal criteria and determining fair values. The abovementioned standard is applicable in cases when the agricultural activity is linked with

- Biological assets;

- Agriculture produce at the point of harvest;

- Government grants under certain conditions.

The standard states that "A biological asset shall be measured on initial recognition and at the end of each reporting period at its fair value less costs to sell, except for the case where the fair value cannot be measured reliably."

The Annual Accounts Law, allows the evaluation of biological assets in their fair value. In order to be able to do it, one of the following parameters has to be abided by:

- the biological asset objects have active market and permanently available market prices;

- it is possible for the biological asset objects with other recognised methods to specify the fair value at the current location and condition thereof.

However, by not addressing the question of determining the fair value of biological assets, we end up in a situation where the value of these assets is false, and we can't fairly evaluate the financial situation and viability of enterprise (Rivzha, Ltimira, 2015). 
ENTREPRENEURSHIP AND SUSTAINABILITY ISSUES

ISSN 2345-0282 (online) http://jssidoi.org/jesi/

2018 Volume 6 Number 1 (September)

http://doi.org/10.9770/jesi.2018.6.1(1)

Recognition of permanent plantations takes place in several stages:

- New plantations are recognized at a value equal to the actual planting costs;

- When the exploitation age is reached, they are estimated at a value equal to the cultivation costs plus the amount determined in the first stage, i.e., the actual cost price;

- If plantations that have already reached the exploitation age are purchased, they are accounted for by the acquisition value.

Animals are valued at the acquisition or production cost or at the lower market prices on the balance sheet date. Productive and working animals are accounted for at their initial value that is formed by adding the acquisition expenses to the acquisition or production costs.

There is particular attention provided to the evaluation issues in the International Accounting Standards, because evaluation is a process of determining monetary units in which the elements of financial statements are recognized and evalued in the entity's balance sheet and profit and loss account. Therefore, it is necessary to choose a particular method for this purpose. The evaluation of biological assets raises problems when there is no single evaluation system determined by, for example, the national standard. Accounts of agricultural businesses in one business sector are incomparable, since every of them uses its own method.

When evaluating biological assets, it should be taken into account that the period of growth of biological assets, in particular long-term plantations and productive animals, is of a lasting nature, and the changes in their fair values during the growing period are significant. If biological assets were valued at the cost price over their entire growth period and would not periodically be revalued at the highest fair value, recognizing their fair value changes in the profit or loss, the income statement would not reflect the economic substance of the biological assets. Therefore, there is a need for a regular revaluation of biological assets at their fair value. The presentation of changes in fair value in the profit and loss account is required for the income, derived from biological assets, to be applied to the reporting periods, when the income is actually earned. Jesemchika (2010) thinks similarly, emphasizing that Latvian legislation does not specify the stage of recognition, which creates confusion in the interpretation of accounting data. 
ENTREPRENEURSHIP AND SUSTAINABILITY ISSUES

ISSN 2345-0282 (online) http://jssidoi.org/jesi/

2018 Volume 6 Number 1 (September)

http://doi.org/10.9770/jesi.2018.6.1(1)

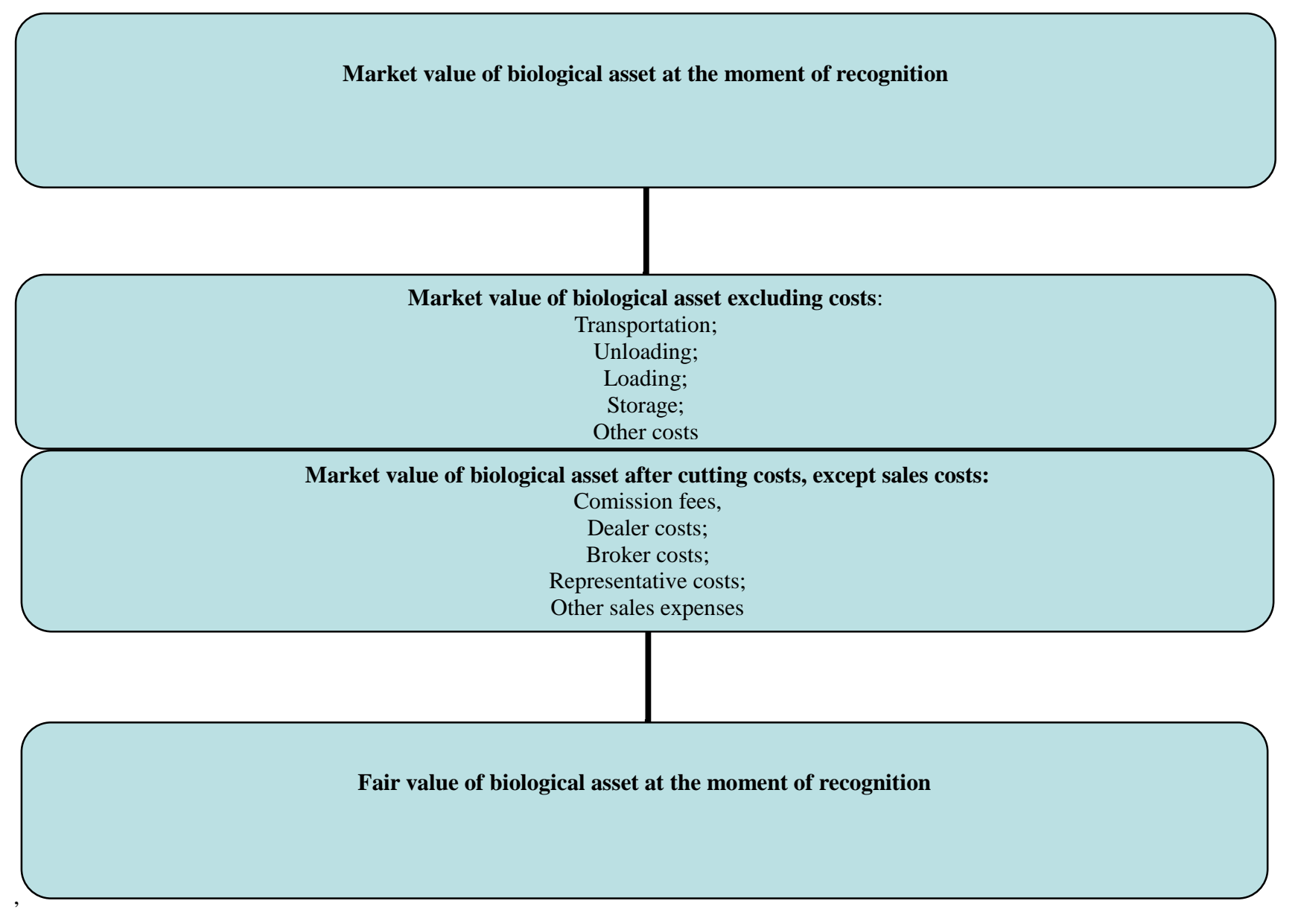

Fig.2. The process of establishing the fair value of biological asset.

Source: Compiled by the authors according to Law on the Annual Financial Statements and Consolidated Financial Statements Latvia and IAS 41-Agriculture

The term "fair value" was introduced in the Latvian accounting laws and regulations in 2003. Law On the Annual Financial Statements and Consolidated Financial Statements defines the concept of "fair value" as the amount received for selling the asset or paid in the normal course of transaction between market participants at the moment of valuation of that asset or liability.

Latvian legislation allows evaluation of biological assets at the fair value less costs, deducting the sales costs if one of two conditions is met, that is, (1) an object of biological assets has active market and permanently available market prices and (2) it is possible to determine the reliable fair value of an object of biological assets using another recognized method at its current place of recognition and condition.

As mentioned above, agricultural products can be obtained from biological assets, while the final products can be obtained from agricultural products. Agricultural products should be valued at their fair value, deducting the estimated point-of-sale costs in the period of harvesting. The evaluation of an agricultural product is on the date of payment, when the 2.IAS Inventory or other relevant standard is applied. 
ENTREPRENEURSHIP AND SUSTAINABILITY ISSUES

ISSN 2345-0282 (online) http://jssidoi.org/jesi/

2018 Volume 6 Number 1 (September)

http://doi.org/10.9770/jesi.2018.6.1(1)

Table 3. Methodology for determining the value of biological assets

\begin{tabular}{|l|l|l|}
\hline \multicolumn{1}{|c|}{ By cost method } & \multicolumn{2}{c|}{ By fair value in an active market } \\
\cline { 2 - 3 } & \multicolumn{1}{|c|}{ Active market available } & \multicolumn{1}{c|}{ Active market unavailable } \\
\hline Choice of cost model & $\begin{array}{l}\text { Calculation of the value of the biological } \\
\text { asset at active market prices }\end{array}$ & $\begin{array}{l}\text { Calculating the value of a biological asset } \\
\text { using value estimation models }\end{array}$ \\
\hline $\begin{array}{l}\text { Changes in the estimated cost of an item } \\
(+/) \text { at its actual cost }\end{array}$ & Estimated sales value & Calculation of the value reduction method \\
\hline $\begin{array}{l}\text { Balance sheet value (initial value after } \\
\text { adjustment, taking into account changes) }\end{array}$ & Calculation of possible costs & $\begin{array}{l}\text { Calculation of the lifetime of a biological } \\
\text { asset }\end{array}$ \\
\hline & $\begin{array}{l}\text { Balance sheet value (fair value and cost } \\
\text { difference) }\end{array}$ & $\begin{array}{l}\text { Balance sheet value (fair value and } \\
\text { depreciation) }\end{array}$ \\
\hline
\end{tabular}

Source: Compiled by the authors according to Law on the Annual Financial Statements and Consolidated

Financial Statements Latvia and IAS 41-Agriculture

In Latvia, preference is given to the evaluation of biological assets at the fair value, and accounting of biological assets at cost price is offered only as an alternative method. During the evaluation of biological assets, it is necessary to assess the conformity of the cost price of a particular asset with its realisable value and choose the most prudent evaluation method (Gulbe, 2015). By assessing, which method of biological assets' evaluation is easier to use, one can conclude that the choice of a method depends not only on the qualification of the accountant, but also on factors such as the availability and quality of statistical information, the flow of the company's information, legislative norms, etc.

\section{Biological assets accounting and evaluation problems in Latvia}

In order to be able to enhance the accurate inventory of biological assets in agricultural holdings, it is necessary to identify current problems and find suitable solutions both from the business community and from the state point of view. In order to facilitate the accurate and prompt accounting in different sectors and businesses, the extensive information both in national regulatory enactments and in international standards on the various aspects of accounting and asset valuation should be available. The authors conclude that sufficient and comprehensible explanatory information regarding the evaluation and accounting of biological assets in Latvia is not provided. Kalnina (2014) points to a number of problems related to the indication of biological assets (animals) in the financial statements. The legal acts of the Republic of Latvia do not explain the accounting principles of biological assets.

Plants and animals are represented in the balance sheet in both inventories and fixed assets. The fixed assets account for working animals and productive animals that meet the criteria of fixed assets. Other animals that do not qualify for recognition of fixed assets are listed in stock. Agricultural enterprises need to determine in their accounting policy whether some of the animals are classified as fixed assets. Taking into account that before introduction of the item "Biological assets" all animals were envisaged to be listed as current assets without providing information requested by the regulatory enactments, many companies continue to list all animals as current assets. That way, they protect themselves from the misinterpretation of the rules of law.

Nowadays, agricultural companies specialize in breeding one kind of livestock for the production of certain commodities, for example, breeding milk cattle for milk production. Therefore, it is not possible to provide the 
The International Journal ENTREPRENEURSHIP AND SUSTAINABILITY ISSUES

ISSN 2345-0282 (online) http://jssidoi.org/jesi/ 2018 Volume 6 Number 1 (September) http://doi.org/10.9770/jesi.2018.6.1(1)

accounting advice that would be equally acceptable for all agricultural enterprises for organization of animal bookkeeping.

In the meaning of the provisions of Law On the Annual Financial Statements and Consolidated Financial Statements of the Cabinet of Ministers, plants are live crops (for example, fruit and berry trees and bushes, cereals, legumes, grasses, root vegetables, herbs, flowers) and wild plants (such as trees and bushes in forest, plants in natural meadow), while perennial plantations are crops that grow on a long-term basis on a given plot of land and give a crop several times (for example, gardens of fruits and berries, including strawberries), as well as nurseries of ornamental and fruit trees and bushes. A proper understanding of the distribution of plants in mono and multi-annual is an essential condition for correct balancing. As accounting practice in Latvia shows, this aspect raises difficulties in cases when an outsourcing company, where the responsibilities of accountants are divided and there is no common understanding about the specifics of the company's work, handles accounting.

The authors believe that one of the aspects in the accounting of biological assets that may contribute to erroneous accounting is that both in case of long-term and short-term biological assets both animals and plants are reflected in one item. That do not provide a clear picture of the biological assets owned by the farm (share of animals and plants).

As far as the assessment of biological assets is concerned, it should be taken into account that there is no active market for most of biological assets and there is no precise information about the value of those assets. This is one of the main reasons why it is rather difficult to apply the principle of fair value in the evaluation of biological assets. According to the Law on the Annual Financial Statements and Consolidated Financial Statements, biological assets are valued at their acquisition or actual production costs and they are gradually depreciated. The legislative norms of the Republic of Latvia do not allow to address issues regarding the determination of the true value of biological assets. As a result, the value of assets is false and it is not possible to fairly assess the company's financial position and viability. A similar view is expressed by Rivzha, Latimera (2015) that the negative consequence of the lack of guidelines and criteria for evaluating biological assets in Latvia is a chaotic and incomparable information on biological assets in annual reports. By examining the experience of legislation of the Republic of Lithuania in relation to biological assets, 17th accounting standard "Biological assets" is applied in the territory of the Republic of Lithuania. This is a significant relief for accountants, as this normative act clarifies and explains the methods of recognition and evaluation of biological assets and the peculiarities of their use. The fair value of biological assets and agricultural products is easier to identify when assets are classified according to their essential characteristics, such as age, weight, quality. Taking into account the classification of biological assets or agricultural products, it is easier to determine their market value. If there is no active market, the fair value of biological assets and agricultural products in the company is determined on the basis of the last transaction price. If the last transaction price and market price significantly differ, the company must find out the reason for the price difference and choose the safest method for determining the fair value of biological assets. From the moment a farmer has chosen the method of evaluation of biological assets - this should be presented in the company's accounting policy. However, if an agricultural enterprise cannot reliably estimate the fair value of biological assets and agricultural products, the standard values approved by the Ministry of Agriculture of the Republic of Lithuania can be used. The authors believe that the process of evaluating the fair value of biological assets and agricultural products is substantially facilitated by the fact that the values presented in the agricultural company's accounting are legally validated, thus reducing the likelihood of errors in the assessment of biological assets.

In the Republic of Estonia, biological assets are accounted for in accordance with the guidance provided by the $7^{\text {th }}$ Estonian Accounting Standard "Biological Assets" and its explanations. The purpose of this legislative act is to 
reflect the rules that must be taken into account when accounting for biological assets. $7^{\text {th }}$ Accounting Standard "Biological assets" provides for rules for the presentation of biological assets in the annual accounts and balance sheet of agricultural enterprises. The standard specifies the recognition and evaluation of biological assets from the initial acquisition value or, in the result of the repeated production process - from the duration of the realization or agricultural production. A large proportion of Estonian agricultural enterprises compile annual accounts on the basis of generally accepted accounting principles. By examining the 7th Estonian Accounting Standard "Biological Assets", it can be concluded that it provides not only a theoretical account of the evaluation and accounting of biological assets, but also examples that allow for a better understanding of these assets and the related economic operations. As the study by Bohushova, Svoboda, Nerudova (2011) suggests, the development of separate standards for the accounting and evaluation of biological assets is not widely practiced. However, the authors are convinced that the experience of Lithuania and Estonia is significant, as all three countries have similar historical experience and the accounting and evaluation of biological assets is a relatively common and important subject of bookkeeping. Consequently, there is a significant informative and methodological support from the legislator, which takes into account both international practice and national characteristics.

The authors believe that the procedure for the inventory and assessment of biological assets should be determined not only by the normative acts of national significance, but also by drawing up a model of the accounting of biological assets for agricultural enterprises. In Latvia, a regulatory framework should be developed to determine: - possible methodologies and criteria for evaluation of biological assets;

- suitable classification.

The existence of such a document, written in a simplified language, would facilitate the process of evaluation and inventory of biological assets and would be an important incentive for the management of agricultural holdings. Moreover, that is essential in current circumstances, when the legislation on accounting allows the owner of the business to conduct accounting himself. That would also be an important contribution to comparing statistics between companies.

Table 3. Biological asset valuation and accounting problems and possible solutions in Latvia

\begin{tabular}{|c|c|c|}
\hline $\mathrm{Nr}$. & Problem & Possible solutions \\
\hline 1 & $\begin{array}{l}\text { There is no complete and unambiguous } \\
\text { information on the assessment and } \\
\text { accounting of biological assets in the } \\
\text { legislation of the Republic of Latvia }\end{array}$ & $\begin{array}{l}\text { The responsible departments of the Ministry of Finance of the Republic of Latvia } \\
\text { are required to develop a bookkeeping and assessment methodological guidance } \\
\text { for "Biological Assets" or "Agriculture" that would explain in detail the current } \\
\text { principles of accounting and valuation of biological assets. } \\
\text { Agricultural companies need to develop and validate accounting regulations that } \\
\text { will ensure more efficient exchange of information between management and } \\
\text { staff. }\end{array}$ \\
\hline 2 & $\begin{array}{l}\text { Representation of both animals and plants } \\
\text { in one balance sheet item. }\end{array}$ & $\begin{array}{l}\text { Legislation should extend the classification of the balance sheet items } \\
\text { "Biological assets" into two sub-items: } \\
\text { - long-term / short-term plantations; } \\
\text { - long/short-lived animals. }\end{array}$ \\
\hline 3 & $\begin{array}{l}\text { A complex process for determining the fair } \\
\text { value of biological assets. }\end{array}$ & $\begin{array}{l}\text { The responsible officials of the Ministry of Agriculture of the Republic of Latvia } \\
\text { should create a single database of the fair values of biological assets depending } \\
\text { on the group of assets and changes in the agricultural sector. The example of } \\
\text { Lithuania is noteworthy. }\end{array}$ \\
\hline 4 & $\begin{array}{l}\text { Agricultural activities influencing factors- } \\
\text { climatic conditions and geographical } \\
\text { remoteness. }\end{array}$ & $\begin{array}{l}\text { The responsible officials of the Ministry of Agriculture of the Republic of Latvia } \\
\text { are to develop an action plan to be implemented in order to reduce the negative } \\
\text { impact of internal and external risks on the operation of the agricultural } \\
\text { enterprise. }\end{array}$ \\
\hline
\end{tabular}

Source: Compiled by the authors 
ENTREPRENEURSHIP AND SUSTAINABILITY ISSUES

ISSN 2345-0282 (online) http://jssidoi.org/jesi/

2018 Volume 6 Number 1 (September)

http://doi.org/10.9770/jesi.2018.6.1(1)

\section{Conclusions}

As a result, it is established that the existing legislation in Latvia regarding the evaluation and accounting of biological assets does not provide sufficient legal provisions, and clarification and comprehensibility of legislative acts. Taking into account the results of the research, as well as the experience of Lithuania and Estonia, it would be useful if the responsible departments of the Ministry of Finance of the Republic of Latvia would elaborate explanatory methodological guidelines for accounting and evaluation "Biological Assets" or "Agriculture" that would explain in detail current principles of accounting and evaluation of biological assets.

The authors believe that one of the aspects of biological assets' accounting leading to erroneous accounting is that both animals and plants are reflected under one item of balance sheet both as long-term and short-term biological assets. It does not provide a clear picture of the biological assets owned by the agricultural enterprise in terms of animal and plant groups. The legal acts should extend the classification of the balance sheet items "Biological assets" into two sub-items: 1) long-term/short-term plantations; 2) long living/short living animals.

The majority of biological assets in Latvia do not have an active market, and there is no precise information on the value of such assets. This is one of the main reasons why it is rather difficult to apply the principle of the fair value in evaluation of biological assets. According to the Law on the Annual Financial Statements and Consolidated Financial Statements, biological assets are valued at their acquisition or actual production costs, and they are gradually depreciated. The legislative norms of the Republic of Latvia do not allow to address issues regarding the determination of the fair value of biological assets. As a result, the value of assets is false, and it is impossible to fairly assess the enterprise's financial position and viability.

\section{References}

Bohušova, H.; Svoboda, P.; Nerudova, D. 2012. Biological assets reporting: Is the increase in value caused by the biological transformation revenue? Agricultural Economics 58(11): 520-532. Retrieved from: http://81.0.228.28/publicFiles/78750.pdf

Gulbe, S. 2015. Gada pārskata sagatavošana- ilgtermiṇa ieguldījumi [Preparation of the annual report - long-term investments] Finanses.lv. Retrieved from https://www.grantthornton.lv/globalassets/1.-member-firms/latvia/pdf/s.gulbe-gada-prskata-sagatavoana-ilgtermiaieguldjumi 2015-02.pdf

Fischer, M.; Marsh, T. 2013. Biological Assets: Financial Recognition and Reporting Using US and International Accounting Guidance. Journal of Accounting and Finance; West Palm Beach.vol.13: 57-74.

Herbohn, K.; Herbohn, J. 2006. International Accounting Standard (IAS) 41: what are the implications for reporting forest assets? Smallscale forest economics, Management and Policy 5(2): 175-189. Retrieved from https://link.springer.com/article/10.1007/s11842-006-0009$\underline{1}$

Jaunzeme, J. 2010. Comparison of the accounting concept „fair value” with other economic value concepts. $11^{\text {th }}$ International Conference. Financial and Monetary Stability in Emerging Countries. 291-298.

Jesemčika, J.; Jesemčika, A. 2010. Accounting of Biological Assets in Latvia. Economic Science for Rural Development Conference Proceedings. Issue 21: 190.-195. Retrieved from http://llufb.llu.lv/conference/economic_science_rural/2010/ESRD_2010_21.pdf

Kalniņa, G. 2014. Dzīvnieku uzskaite grāmatvedībā un atspoguḷošana gada pārskatā. Bilance [Animal records in accounting and presentation in the annual report. Balance], 339-340. Retrieved from https://bilance.lid.lv/

Lefter, V.; Roman, A.G. 2007. IAS 41 Agriculture: Fair Value Accounting. Theoretical and applied Economics 5(510): 15-22. Retrieved from https://econpapers.repec.org/article/agrjournl/v_3a5(510)_3ay_3a2007_3ai_3a5(510)_3ap_3a15-22.htm 
Mateş, D.; Grosu, V. 2009. Evaluating and recognizing biological assets and agricultural activities according to IAS 41. Lucrări Ştiinţifice seria Agronomie 51, vol.3: 1-6. Retrieved from http://www.revagrois.ro/PDF/2008 1 457.pdf

Ore, M. 2011. Problematic Aspects of Accounting for Biological Assets. Proceedings of the International, Scientific Conference. Production and Taxes. Jelgava: Vidzeme University of Applied Sciences, 204.-210. Retrieved from http://llufb.llu.lv/index_en.html

Rivža, B.; Latimira, I. 2015. Problems of recording biological assets and legislation shortcoming in Latvia, possible solutions. Nordic view to sustainable rural development. $25^{\text {th }} \quad$ Congress. $472 .-473 . \quad$ Retrieved from http://llufb.1lu.1v/conference/NJF/NJF_2015_Proceedings_Latvia-472-473.pdf

Riigi, T. 2011. Rtj 7 bioloogilised varad. Retrieved from https://www.riigiteataja.ee/akt/310012012005

Vooro. A. 2011. Bioloogiliste varade kajastamine raamatupidamises. Tartumaa Põllumeeste Liit. [Accounting of biological assets in accounting]. Tartumaa Farmer's Union Retrieved from http://www.rmp.ee/epood/tasutaraamatud/raamatupidamine/1018

Gada pārskata un konsolidēto gada pārskatu likuma piemērošanas noteikumi. Ministru kabineta noteikumi Nr.775. [Rules for the application of the Annual Report and the Consolidated Annual Report. Cabinet of Ministers Regulations No. 755 ]. 2015. of Latvia Law. Retrieved from Latvian Central Statistical Bureau. Statistical Enterprise register. Economically active enterprises by main

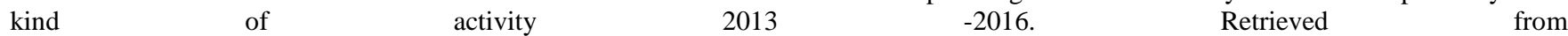
http://data.csb.gov.lv/pxweb/lv/uzreg/uzreg_ikgad_01_skaits/SRG0201.px/table/tableViewLayout2/?rxid=cdcb978c-22b0-416a-aacc$\underline{\text { aa650d3e } 2 \mathrm{ce} 0}$

Latvian Central Statistical Bureau. 2017. Agriculture in $\quad$ Latvia. Retrieved from http://www.csb.gov.lv/sites/default/files/nr_24_latvijas_lauksaimnieciba_2017_17_00_lv_en_0.pdf

Law On the Annual Financial Statements and Consolidated Financial Statements. 2015. Republic of Latvia Law. Retrieved from https://likumi.lv/ta/en/id/277779-law-on-the-annual-financial-statements-and-consolidated-financial-statements

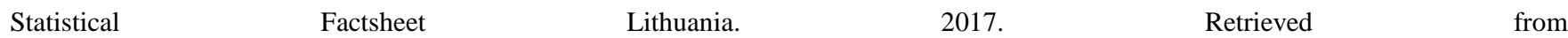
https://ec.europa.eu/agriculture/sites/agriculture/files/statistics/factsheets/pdf/lt_en.pdf

Statistical country $\quad$ profiles $\quad$ Estonia. $\quad$ Special $\quad$ edition $\quad 2017 . \quad$ Retrieved from https://www.destatis.de/EN/Publications/Specialized/InternationalData/CountryProfiles/Estonia2017.pdf? blob=publicationFile

Starptautisko grāmatvedības standartu padome International [Accounting Standards Board]. 2003. 41.starptautiskais grāmatvedības standarts. Lauksaimniecība:521.- 375. Retrieved from http://eur-lex.europa.eu/legal-content/LV/TXT/PDF/?uri=CELEX:02008R112620160101\&from $=\mathrm{LV}$

Viešosios įstaigos Lietuvos Respublikos apskaitos instituto standartų tarybos. [n.d.] 17-asis verslo apskaitos standartas „,biologinis turtas” [Standards Board of the Public Institution Institute of Accounting of the Republic of Lithuania. [n.d.] Business Accounting Standard 17 "Biological Assets"]. Retrieved from: http://www.bankrotodep.lt/assets/Veiklos-sritys/Apskaita/VAS/Priimti-standartai/17-VAS-5redakcija.pdf

Lietuvos Respublikos žemės ūkio ministerija. (2015, 27 Nov.). Dėl biologinio turto ir žemès ūkio produkcijos normatyvinių kainų 2016 metais sąrašo patvirtinimo Ministry of Agriculture of the Republic of Lithuania. (Nov. 2015). [On approval of the list of normative prices for biological assets and agricultural produce in 2016]. Retrieved from http://www.bitininkusajunga.lt/lt/Teises_aktai/Biologinio_turto_ir_zemes_ukio_produkcijos_normatyviniu_kainu_sarasas_/ 
ENTREPRENEURSHIP AND SUSTAINABILITY ISSUES

ISSN 2345-0282 (online) http://jssidoi.org/jesi/

2018 Volume 6 Number 1 (September)

http://doi.org/10.9770/jesi.2018.6.1(1)

Iluta ARBIDANE is the Professor of Faculty of Economics and Management of Rezekne Academy of Technologies, Latvia. She is former Dean of Faculty of Economics, director of study programmes, Research interests: accounting and finances, human resources management. ORCID ID: 0000-0002-9762-3874

Iveta MIETULE is the Professor of Faculty of Economics and Management of Rezekne Academy of Technologies, Latvia. She is Dean of Faculty of Economics and Management, director of study programmes, Expert of Latvian Council of Sciences. Research interests: accounting, higher education, human resources, regional development.

ORCID ID: 0000-0001-7662-9866

Register for an ORCID ID:

https://orcid.org/register

Copyright (C) 2018 by author(s) and VsI Entrepreneurship and Sustainability Center

This work is licensed under the Creative Commons Attribution International License (CC BY).

http://creativecommons.org/licenses/by/4.0/

c) (i) Open Access 